\title{
From apathy to oblivion? The shameful history of heritage resource management in the Vaal Triangle
}

\author{
MARGUERITE PRINS*
}

\begin{abstract}
The Vaal Triangle is richly endowed with a prehistory that commenced c. 1.5 million years ago, when a succession of Stone Age cultures flourished in the fertile Vaal-Klip valley in the environs of the modern industrial city of Vereeniging. The numerous stone artefacts scattered throughout the area, attest to these ancient settlements. During the Iron Age, the sandstone outcrops in the valley provided a durable surface for engraving - a manifestation of the burgeoning ability of humankind to give pictorial form to experiences and ideas. Due to the efforts of a few concerned individuals, the prehistoric sites in the Vaal-Klip valley received international acclaim and recognition. In 1943 and 1944, the two most important Stone Age archaeological reserves were officially declared national monuments, followed by the Redan rock engraving site in 1971. Over an extended period of time the two bodies responsible for their maintenance, the local government and the official heritage body of the day, conducted extensive negotiations, but failed to save these sites. With the exception of Redan, all the previously listed rock engraving sites, and the two Stone Age archaeological reserves, have been completely obliterated. Redan has become progressively neglected and abandoned. This paper examines the impasse presently surrounding Redan, and the failure of the relevant bodies, to conserve and sustain the non-renewable prehistoric culture remains of the Vaal Triangle.
\end{abstract}

Keywords: Stone Age, Iron Age, prehistoric culture remains, rock engravings, heritage resource management, South African Heritage Resources Agency (SAHRA), intellectual property.

Disciplines: Archaeology, History of Art, Anthropology, Heritage Studies, History and Tourism Studies

\section{The prehistoric roots of Vereeniging}

Rock, the most enduring element in the landscape, has been used since remotest times by humankind to create material culture, ranging from stone artefacts used for hunting and protection, to the enigmatic images engraved on the face of the rock. No doubt, attracted to the

Marguerite Prins, freelancer, previously Senior Chief Education Specialist (Arts and Culture), Gauteng Department of Education, completed a PhD in history at NorthWest University in 2005. An earlier draft of this article was presented at a conference of the South African Visual Arts Historians (SAVAH), at the Vaal University of Technology in September 2006.

TD: The Journal for Transdisciplinary Research in Southern Africa, Vol. 3 no. 1, July 2007, pp. 39-52. 
waters of the Vaal and the abundant supply of smoothly polished pebbles, successive Stone Age communities settled in the Vaal-Klip valley on the outskirts of modern Vereeniging. The numerous stone artefacts scattered throughout this area, attest to these ancient settlements. The great antiquity of tool-making in the Vaal area is confirmed by Deacon and Deacon (1999:82) '... most of the Acheulean sites in the Vaal basin probably date between 1 million and 500000 years ago...' The Acheulean handaxes and cleavers of the Earlier Stone Age, recovered at Klipplaatdrift and Duncanville, appear to have been made according to a preconceived design. They range in length from $100-200 \mathrm{cms}$, are frequently bifacial (shaped by flaking on both sides) and present a symmetrical appearance, suggesting that even during this early period, humankind was already endowed with a creative urge, the striving to go beyond the primary level of function. Approximately 25000 years ago these large bifaces were replaced throughout South Africa by the flake industries of the Middle Stone Age (MSA). MSA artefacts are characterised by a decrease in size, the removal of more flakes, deliberately faceted platforms, secondary preparation technique, and improved symmetry (see Mitchell 2002:63). These finely crafted MSA tools are scattered throughout the southern Highveld, including the Vereeniging area. The MSA artefacts of the Vaal-Klip valley are aptly described by Mason in precise geometrical terms as e.g. pyramidal, cuboid, circular and triangular (1962:253-262).

Mason (ibid: 283-279) further suggests that earlier generations of Stone Age peoples transmitted their methods to later generations who made small improvements in the original design, and that this creative process originated in the Vaal-Klip valley, before spreading to other areas in South Africa. The art historian and philosopher, Herbert Read (1965:66), reflects on this progressive refinement of form in prehistoric stone industries:

Why out of the shapeless chaos of sticks and stones, or out of the handy and useful objects which were the first tools of primitive man, did form progressively emerge until it surpassed the utilitarian purpose of the shaped object and become form for the sake of form, that is to say the work of art?

This ability to transform immutable stone into objects of astonishing beauty, would culminate about 20000 years ago in the microlithic artefacts of the Later Stone Age. Stone tools were reduced to c. 15 $\mathrm{mm}$ in length (Mason 1962:328), showing that the progressive miniaturisation had reached its logical end. The discovery of the grinding technique facilitated the shaping of stone into spheroids, the manufacture of ostrich eggshell beads and minute bone artefacts, and the manufacture of pigments from ochre and haematite. Mitchell (2002:17) concisely describes this period as the 'replacement of Middle Stone Age working traditions by Later Stone Age (LSA) microlithic technologies and the first unambiguous widespread signs of symbolic activity in the form of art and jewellery'. 


\section{The discovery of pictorial form}

At Olieboompoort, some distance away from the Vaal area, and dated to c. $870 \pm 150 \mathrm{BP}$, Mason recovered an abundance of minute stone artefacts, and fragments of bone incised with simple geometric patterns (1962:310). Mason (ibid: 321) suggests that these 'engraved designs provide a tenuous link with painting and engraving on rock'. In spite of many missing parts, it can be assumed that imperceptibly, and over a vast period of time, pictorial form was discovered - the ability to make meaningful marks on a hard surface, leaving a permanent record of beliefs, ideas and experiences. This unique human ability also manifested in the Vaal-Klip Valley. According to the survey, that Van Riet Lowe conducted of all known rock art sites in South Africa, there were seven rock-engraving sites in the Vereeniging area (Van Riet Lowe 1952:12). A few engravings can still be located on a portion of the farm Leeukuil, presently a small island in the Vaal River near Vanderbijlpark. However, the majority of these engravings are already submerged beneath the waters of the Vaal. These isolated examples, plus the rock engravings of Redan in the Vaal-Klip Valley, are the only prehistoric culture remains of the once rich prehistoric legacy of the Vaal Triangle.

\section{The Redan rock engraving site}

The engravings of Redan occur on an isolated sandstone outcrop on the farm Kookfontein, in what was formerly a coal-mining area. A distant mine dump and a number of graves dating from the 1960s (presumably of black miners), are all that remain of earlier, more prosperous times. The outcrop consists of 33 separate rock surfaces of varying heights and slopes down to a muddy stream that previously flowed freely into the Klip River. The proximity of the engraving site to a stream is significant. A statistical analysis by Fock and Fock (1989:154) of the distribution of the rock engravings of the Vaal-Orange basin, shows that the greatest concentration of 'geometrics ... occurs on higher surfaces or uplands, but adjacent to small streams, springs ... where water is a prime criterion ...'. Engravings occur on only 18 of these rock surfaces at Redan. Of the total number of 273 engraved images, 10 can be identified as animals; the remaining 263 images are geometrically constructed and totally non-representational (see Prins 2005). The most outstanding feature of these 'geometric' images is the predominance of the circle; each of these circular images is unique. The elevated outcrop is a powerful presence in the flat Highveld landscape; from this secure base, the ancient engravers could contemplate the wide expanse of veld, watch approaching game, and mark the rock face with countless circular images. The question 
invariably asked is, how old are the engravings and who made them? Modern Khoisan do not engrave or paint on rock, and have no recollection of an ancestral rock art tradition. In spite of recent advances in radiocarbon dating, and the introduction of the new accelerator radiocarbon techniques, the dating of rock art, particularly rock engravings, remains problematic (see Deacon \& Deacon 1999:1113; Hall 1996:121-126).

\section{Unresolved issues of age and authorship}

Conclusive dating has only been possible in those rare instances where the art occurs on portable stones. Dating is made possible by analysing the residues of organic material found in the occupation levels of excavated sites. The most spectacular example of this nature was found in 2002 in the Blombos Cave near Stilbaai (see Henshilwood 2002). The small piece of red ochre with its carefully incised pattern of regularly spaced chevrons, and dated $77000 \mathrm{BP}$, effectively pushes back the period in which rock art is believed to have originated. It pre-dates the small mobiliary slab that was retrieved from Wonderwerk Cave near Kuruman, and dated 10000 BP (Deacon \& Deacon 1999:164). In spite of these spectacular finds, there is consensus that the vast majority of rock art was produced within the past 2000 years (Mitchell 2002:194). No scientific dating has ever been done at Redan. Considering the absence of an established chronology, and based on the calibrated dates obtained at Driekopseiland and Klipfontein in the Northern Cape (Whitley \& Annegarn 1994:194-196), and given the similarity between the engravings at these sites and at Redan, it can be surmised that the rock engravings of Redan span a period of a few hundred to possibly several thousand years.

Approximately 2000 years ago, the relatively peaceful lives of the Later Stone Age hunter-gatherers would be changed under the impact of two major events - the appearance of the Khoekhoen (Khoi) herders and their livestock, and the arrival of the Bantu-speaking agropastoralists from the north (Hall 1987:13; Deacon \& Deacon 1999:195). Traditionally, the vast majority of both rock paintings and rock engravings were ascribed to the San (Lewis-Williams 1989:8; Hall 1987:215). However, recent research points increasingly to a Khoekhoe or Khoisan authorship for the majority of rock engravings. In a groundbreaking paper, Smith and Ouzman (2004) argue for a Khoekhoe origin for the rock engravings of southern Africa. Referring to aspects such as site preference along water courses, geographic distribution, iconography and associated contents, the authors conclude that the rough-pecked, non-representational and geometric rock engravings of southern Africa (and by implication also the rock engravings of 
Redan), were executed by Khoekhoen herders (Smith \& Ouzman 2004:515). A table is included, illustrating the range of geometric imagery in southern African herder rock art (ibid:505, fig. 5). Although Redan is not mentioned in the text, at least eight of the images are from Redan - a further indication of a Khoekhoe origin for the engravings.

The historic record also confirms a strong Khoekhoe presence on the southern Highveld during the early 1800s. This area across the Vaal, the trans-Vaal, was penetrated by white people for the first time when the missionaries Hodgson and Broadbent established a mission station at Matlwase (Maquassi) near modern Klerksdorp. The journals of the Rev. T.L. Hodgson, published for the first time in 1977 (Cope (ed.) 1977), provide a detailed account of events on the southern-western Highveld between 1823 and 1825. It also records the complexity of human interaction of the different ethnic and cultural groups during the Difaqane. In the course of his evangelical work on the Highveld, Hodgson encountered no less than 10 different migratory groups, including the two nomadic groups that had lived in the area for thousands of years, the Khoekhoen, and the San (Khoisan). The group most frequently encountered were the Korana branch of the Khoekhoen. After the Difaqane, the entire Highveld was depleted of its once thriving communities and only small pockets of survivors remained. The first white trekboers moved into the area from 1836, bringing indentured Khoisan with them, and influxes of Nguni and Sotho people also gradually returned (Wilson \& Thompson (eds.) 1969:409-411). However, the cultural composition and group identities of pre-Difaqane years was irrevocably and permanently destroyed (see also Maggs 1976:310; 322).

\section{An industrial giant is born}

One of the first trekboers to settle in the Vaal-Klip Valley was a C.A. Pistorius, who gave his farm the appropriate name of Klipplaatdrift to describe the huge quantities of stones along the banks of the Klip River (Leigh 1968:17). Pistorius had chosen to settle on the same stretch of land where early man had created his first stone artefacts and taken the first tentative steps towards industrialisation. Coal occurred on many of these early farms, and G.W. Stow was instructed to buy a large number of these coal-bearing farms (Mendelsohn 1991:11). The farm Leeukuil was bought in 1880, and one year later, after much negotiation, the neighbouring farm of Klipplaatdrift was also acquired (Leigh 1968:17). The first mining operations commenced at Bedworth Colliery (later known as Central Mine) on a portion of Leeukuil (Willemse 1999:24-28). The rapidly growing population of 
miners and shopkeepers were soon in urgent need of residential land, and in 1889, the first town plans were drawn up by J. Rissik, and pegged out by E. Jorissen (Leigh 1968:21). Portions of both Leeukuil and Klipplaatdrift were included in the town plans and on 29 July 1892 , the village of Vereeniging was officially proclaimed. The fact that ancient rock engravings occurred on both these farms (Van Riet Lowe 1952:12), and the possibility of conserving them as valuable prehistoric culture remains of the past, did not occur to the government officials who drew up the plans. In the ensuing years, the many collieries and related steel industries would shape the cultural landscape, and in the process erase all signs of the area's prehistoric past. All traces of these rock-engraving sites have since vanished.

\section{Restitution and official recognition}

The rock engravings of Redan on the farm Kookfontein, were more fortunate. The rock engravings were probably saved from annihilation because they occurred directly next to Springfield Colliery, and the land was therefore not considered suitable for residential development. At the turn of the previous century and through the efforts of the Vereeniging pioneer T.N. Leslie, the rock engravings of Redan were brought to the attention of the authorities in the Cape (Vaal Teknorama Archives Depot 03/13558). In spite of the fact that no heritage legislation was yet in place in South Africa, the engravings were visited and described by a number of eminent international visitors (see Pöch 1908; Johnson 1910). This publicity was instrumental in the promulgation of the first heritage legislation ever in South Africa, the Bushman Relics Protection Act No. 22 of 1911. In the ensuing years this act would be revised and replaced several times (see Rudner 1989). In 1934 the Natural and Historical Monuments, Relics and Antiques Act, No. 4, made it possible for the first time to declare particular sites national monuments (Deacon 1991:230). This coincided with the appointment in 1935 of Van Riet Lowe as the secretary of the Historic Monuments Commission (HMC). Prior to his appointment, Van Riet Lowe had displayed considerable interest in the prehistory of the Vaal area, and had accompanied a number of international delegates to the prehistoric sites in Vereeniging (Mason 1989:59).

Van Riet Lowe soon became a major force in the investigation, excavation and conservation of the prehistoric sites in the Vereeniging area. Due to his efforts, the Kliprivier Archaeological Reserve in the Klipplaatdrift area was proclaimed a national monument in 1943 (SAHRA File no. 9/2/277/9;3/1/8/Ver/5). One year later, in 1944, a second Earlier Stone Age site in the same vicinity, the Van Riet Lowe 
Archaeological Reserve, was proclaimed. Research undertaken in the 1960s by Revil Mason, confirmed the archaeological significance of both sites (see Mason 1962). The plaque erected at the Van Riet Lowe Archaeological Reserve included the following wording:

\begin{abstract}
Millions of years ago, when the level of the Vaal River was 320 metres higher, it flowed across the area and deposited gravels, which later became sources of material for tool-making for Stone Age people. The site yielded large quantities of stone implements which suggest that the people who made them were related to the Early Stone Age occupants of the Sterkfontein caves ... (SAHRA File no. 9/2/277/5 (6/7 Ver/2 or 3/1/3/Ver/4).
\end{abstract}

The plaque disappeared in the 1990s, and was probably stolen. It was never replaced. These two sites received international recognition and were frequently visited by delegates who removed large numbers of Acheulean artefacts to museums in France and England (Mason 1989:24).

\title{
The relentless cycle of neglect, reparation and obliteration
}

Having put the tool-making ability of early man on the international map, Van Riet Lowe turned his attention to the other great legacy of early humankind in the Vereeniging area, the art-making ability. Of the seven rock engraving sites in the area, Redan was the most significant. After World War I (1914-1918), the need for agricultural land increased dramatically and the farm Kookfontein, on which the engravings occur, was acquired by the Vereeniging Town Council (VTC) and made available to a succession of small farmers, with no interest in the prehistoric site or obligation to maintain it. In future, the VTC and the official heritage body would be jointly responsible for the maintenance of the prehistoric sites of Vereeniging. The site deteriorated rapidly and there was no effort to maintain it. The 1950s heralded a period of endless negotiations and wrangling between the two official bodies concerned, the HMC and the VTC. The former did not have the human resources or funds to intervene, the latter was unwilling to take responsibility for the site, or cover any costs involved. Desperate to save Redan from further neglect, Van Riet Lowe made the fatal error of commissioning the removal from Redan, of its largest and arguably most spectacular engraving. Presently it is housed at the Rock Art Research Institute (RARI) of the University of the Witwatersrand. Van Riet Lowe died in 1956 and was succeeded by B.D. (Berry) Malan. Malan would continue the work that his predecessor had initiated in the Vereeniging area.

The fence around Redan was repaired, and a small investigative committee was appointed by the Council for Scientific and Industrial Research (CSIR) to research the in situ preservation of the engravings. 
Unfortunately, none of the recommendations were implemented. In 1967, a grant was obtained from the CSIR, and the entire site was recorded for the first time (see Willcox \& Pager 1967). Malan worked tirelessly to improve heritage legislation and in 1969 the HMC was replaced by the National Monuments Council (NMC). Staff was expanded, more funds were made available, and district representatives were appointed (Rudner 1989:3). Alerted by the Willcox/Pager report, Malan sent Prof. J.F. Eloff to inspect Redan. Eloff was horrified at the appalling conditions at the site and expressed his shock in graphic terms: '.. The rock surface on which the engravings occur is covered with the excrement of people, pigs and cattle ... in some areas fires were lit ... rocks are blackened and the surface has cracked...' (Vaal Teknorama Archives Depot 122/2. Correspondence 22 May 1970).

This damning report had the desired effect. A strong, protective fence was erected around the site by the VTC and in 1971 Redan was officially declared a national monument (SA Parliament 1971). These favourable conditions declined sharply after Malan's death. Within a few years the cycle of neglect and deterioration had set in once more - it would continue ad nauseum. In spite of Redan's new status as an officially proclaimed national monument, the site rapidly became neglected and abandoned. In the past, a few concerned individuals had always intervened on behalf of the prehistoric sites of Vereeniging. This concern lasted as long as these individuals were alive, but declined sharply after their deaths.

In 1978 the role of unofficial custodian of Redan was taken over by Baby Deyzel, curator of the museum section of the public library and later director of the Vaal Teknorama museum. She became a passionate spokesperson for the preservation and maintenance of the three prehistoric sites in Vereeniging and acted as mediator between the two official bodies concerned, the VTC and the NMC. At her insistence, a small delegation of NMC officials visited the three prehistoric sites in 1984, in order to evaluate their potential. The two Stone Age sites were found to have 'very low potentials for development as site museums' ... and that 'the public should be discouraged from visiting .... (Vaal Teknorama Archives Depot 122/2. Correspondence 2 Aug. 1984). These findings sounded the death knell for both the Kliprivier and Van Riet Lowe Archaeological Reserves, and marked the onset of their total demise. Although both sites are still indicated on the most recent maps of Vereeniging, all traces of their former existence have vanished. At the Kliprivier site, the ground has reverted to scrub, the crumbling stone monument has been stripped of its commemorative plaque, and the base is littered with broken bottles and rubbish. The Van Riet Lowe site has been converted into an enclosed pen and pond for small animals. Sheep graze and pigs wallow in mud, where the earliest known inhabitants of the area established 
their stone industry, and where international delegates collected these artefacts for European museums in the 1940s. Redan was more fortunate. The official delegation of 1984 found the site in 'good condition' and they recommended that protective roofing and a catwalk be installed across the engraved surface of the outcrop. These ambitious plans did not materialise, but Deyzel continued exercising control over visits to the site, and ensured that regular payments towards its maintenance, were received from the NMC.

\section{SAHRA and the failure of heritage resource management in the Vaal Triangle}

In 1994 the democratically elected Lekoa Vaal Metropolitan replaced the VTC, automatically inheriting the responsibility of Redan. Due to illness Deyzel retired in 1997 and her post remained vacant. On 28 May 1999, the farm Kookfontein that had been owned and managed by the VTC for almost 100 years, was sold to a private individual, K. Badenhorst. The Kopanong Metropolitan Substructure drew up the contract but failed to inform Badenhorst of the significance of Redan, or include a clause in the contract and title deeds of the conditions applying to heritage sites (Badenhorst 2003). A month prior to this event, new heritage legislation was introduced and the South African Heritage Resources Agency (SAHRA), replaced the previously designated NMC. A significant change in the act was the establishment of a system for grading sites as either national, provincial or local, and their assessment and management by SAHRA representatives (SA Parliament 1999). No provincial heritage authority had been appointed, and Badenhorst was effectively barred from taking any action. Within months the site was severely vandalised, the gate and official plaque disappeared, and the protective fence was systematically removed. A cause for further concern was the extreme exfoliation of the rock surface and the possibility that some of the engravings had already disintegrated. Many of the engravings are currently (2007) so severely weathered that it is difficult to distinguish them from the rock surface. Appalled at these conditions, Prof. Johann Tempelhoff of the North-West University (formerly PU for CHE) and a few concerned individuals including myself, formed a small informal committee in order to address the deplorable conditions at Redan, and formulate a plan of action.

Alerted by these developments, members from SAHRA visited Redan in May 2000, and informed Badenhorst of the new legislation regarding heritage sites and his obligations as landowner (SAHRA File no. 9/2/ $277 / 17 \mathrm{~F}, 3$ Aug. 2000). This was followed by a second visit in which the acting director of the local museum, the Vaal Teknorama and 
members of RARI also participated. The Van Riet Lowe and Kliprivier Archaeological reserves were also visited, and found to be almost completely obliterated, and were deemed 'to be of no interest for the general public ...' Redan was found to have 'a profusion of good quality engravings ...' (SAHRA File no. 9/2/277/17F, 21 Sept. 2000).

A feasible business plan for the management of Redan was drawn up by RARI (see SAHRA File no. 9/2/277/17F, 3 Aug. 2001), and given to Badenhorst. However, this did not solve his predicament as a provincial heritage resources authority had yet to be appointed to approve and monitor any practical activity at the site. In the ensuing months, correspondence passed between the authorities concerned and various plans of action were suggested and considered. Nothing came of these plans and correspondence finally ceased. The status quo of Redan remained unchanged.

Rapid changes in local government in the Vaal Triangle added further instability to the unsatisfactory conditions prevailing at Redan. The Sedibeng District Council replaced the Lekoa Vaal Metropolitan Council. In his inaugural speech, Peter Skosana, the executive mayor, emphasised that the council was committed to regenerating the economy, and that cultural tourism was a potential source of income for both the white and black sectors of the community. A number of resources were mentioned, including the Dutch reformed Church (NGK) Klipkerk, the place where the Anglo Boer War peace treaty was negotiated, and the Sharpeville Monument. No mention was made of Redan, and the contribution of the Khoisan peoples and the potential of this prehistoric site as an important cultural tourism destination was overlooked (Vaal Teknorama Archives Depot. Sedibeng District Council documents file. 16 Feb. 2001).

This omission was probably because no single ethnic or cultural group in the Vaal Triangle had sought ownership and claimed intellectual property rights of Redan.

Between 2000 and 2005 all communication ceased between the parties concerned and the site rapidly reverted to its former state of neglect. In the past, the two main role players, the National Monuments Commission and the Vereeniging Town Council, had been engaged in endless negotiations, and had displayed an inability to conceptualise a practical plan of action. In spite of a democratically elected new local government and encompassing heritage legislation, history was repeating itself.

\section{The demise of Redan?}

In October 2005 the farm Kookfontein changed hands once more and was sold to Purple Rain Properties and their subsidiary Ocon Bricks, 
with the intention of mining clay for the manufacture of bricks. Fully aware of their obligations as landowners of a property on which a heritage site occurs, and eager to comply with heritage legislation, Jan Viljoen of Ocon Bricks arranged a meeting between all interested parties. The meeting took place in December 2005 and included an official from the Vaal Teknorama, Prof. Tempelhoff of North-West University, and myself. SAHRA was not represented. As an interim measure, and in order to protect the site from further vandalism, Viljoen undertook to execute and finance the following:

- erect a steel palisade fence around the engraving site;

- clean the site of weeds and debris; and

- provide a proper public entrance (at present, access to the site is through the grounds of the adjacent Springfield School).

A proposal to this effect was submitted to SAHRA on 25 January 2006, and further instructions and guidance were awaited (Viljoen, April 2006). SAHRA failed to respond. During the 2006 Biennial Meeting of ASAPA (Association of Southern African Professional Archaeologists), 9-13 April 2006, I attempted to discuss the urgency of the matter with a representative of SAHRA (Kitto 2006). The response was negative and non-committal.

After numerous telephonic conversations SAHRA finally responded in September 2006 (Viljoen, Sept. 2006). Viljoen's offer of an interim fence was rejected and he was instructed to comply in all respects with the regulations and requirements as set out in Section 35(4) of the new Heritage Act (SA Parliament 1999). In effect, a special permit was required before any material at the site (e.g. debris and weeds) could be disturbed or altered in any way whatsoever. Upon acceptance of such a permit, the landowner is then required to follow a number of prescribed procedures - and cover all costs involved. These procedures include the following: appointing an approved heritage practitioner to conduct a comprehensive heritage impact assessment; drawing up a heritage management plan; and providing detailed specifications and architectural drawings of the proposed alterations. According to Ocon Bricks (Viljoen, Sept. 2006), this entire operation will cost approximately R100 000 - an exorbitant figure as compared to the cost of erecting a simple palisade fence around the site. Due to what is perceived as the unreasonable and unrealistic demands of SAHRA, Ocon Bricks are no longer prepared to participate in the conservation of Redan and have withdrawn their support.

Consequently, all communication between Ocon Bricks and SAHRA has abruptly come to a standstill. The battle that has raged since the 1940s between local and governmental institutions, regarding the conservation of Redan, has finally ceased. 


\section{Conclusion}

In order to address this impasse, existing institutions and persons that have in the past, displayed an interest in Redan, such as the Vaal Teknorama and the Vaal Triangle Campus of North-West University, should continue in their efforts to create and foster public awareness. The guidance and active participation of SAHRA and of the local government should be pursued. Finally, the constructing and reinforcing of group identity - especially a Khoisan interest group in the Vaal area, should be explored. Visits to Redan continue to take place on an ad hoc basis, loosely supervised by the interested parties themselves. However, the relentless cycle of neglect continues unabated. The site is overgrown with weeds and the engravings are littered with debris. Tall grass is rampant between the rocks, obscuring many of the engravings. An ominous silence hangs over the site; the only sound is that of water pouring into a huge sinkhole that caved in recently, immediately next to the engraving site. This poses a further threat to the conservation of these valuable non-renewable prehistoric culture remains. Like the wild animals that once roamed freely in the area, and have since disappeared, the demise of Redan is imminent.

\section{References}

Badenhorst, K. 2003. Personal interview. 17 April, Vereeniging.

Cope, R.L. (ed.) 1977. The journals of the Rev. T.L. Hodgson: missionary to the Seleka-Rolong and the Griquas 1821-1831. Johannesburg : Witwatersrand University Press.

Davenport, T.R.H. 1989. South Africa: a modern history. Bergvlei : Southern Book Publishers.

Deacon, J. 1991. South African rock art and the National Monuments Council: In: Pager, S-A., Swartz, B.K. Jr., Willcox, A.R. (eds.) Rock art: the way ahead. Papers from the First International Conference of the Southern African Rock Art Research Association: 229-234. Johannesburg : SARARA Occasional Publications.

Deacon, H.J. \& Deacon, J. 1999. Human beginnings in South Africa: uncovering the secrets of the Stone Age. Johannesburg : David Philip.

Fock, G.J. \& Fock, D. 1989. Felsbilder in Südafrika. Teil III : Die felsbilder im Vaal-Oranje-becken. Köln : Böhlau Verlag.

Hall, M. 1987. The changing past: farmers, kings and traders in 
southern Africa, 200-1860. Cape Town : David Philip.

Hall, M. 1996. Archaeology Africa. London : James Currey.

Henshilwood, C. 2002. Blombos - a tale of two engravings. The Digging Stick 19(2):1-5.

Johnson, J.P. 1910. The prehistoric period in South Africa. London : Longmans, Green \& Co.

Kitto, J. 2006. Personal interview. 9 April, Pretoria.

Leigh, R.L. 1968. Vereeniging. Johannesburg: Courier-Gazette.

Lewis-Williams, J.D. \& Dowson, T.A. 1989. Images of power: understanding Bushman rock art. Johannesburg : Southern Book Publishers.

Maggs, T. 1976. Iron Age communities of the southern Highveld. Pietermaritzburg : Natal Museum.

Mason, R. 1962. Prehistory of the Transvaal: a record of human activity. Johannesburg : Witwatersrand University Press.

Mason, R. 1989. South African archaeology 1922-1988. Johannesburg: Archaeological Research Unit, University of the Witwatersrand, Occasional Paper 22.

Mendelsohn, R. 1991. Sammy Marks: the uncrowned king of the Transvaal. Cape Town : David Philip.

Mitchell, P. 2002. The archaeology of southern Africa. Cambridge : Cambridge University Press.

Pöch, R.I. 1908. Buschmanns-Gravierungen auf Vereeniging. Anz Akad. Wissench. 130.

Prins, M. 2005. The primordial circle: the prehistoric rock engravings of Redan, Vereeniging. Unpublished D.Phil thesis, School of Basic Sciences, North-West University.

Read, H. 1965. The origins of form in art. London : Thames and Hudson.

Rudner, I. 1989. The conservation of rock art in South Africa. Cape Town : National Monuments Council.

SAHRA (Southern African Heritage Resources Agency), Provincial Office, Gauteng. File no. 9/2/277/17F, 21 Sept. 2000.

File no. 9/2/277/17F. Management guidelines for the Redan engraving site, Vereeniging, Gauteng, South Africa, 3 Aug. 2001.

File no. 9/2/277/9;3/1/8/Ver/5.

File no. $9 / 2 / 277 / 5$ (6/7 Ver/2 or $3 / 1 / 3 / \operatorname{Ver} / 4)$. 
Smith, B.W. \& Ouzman, S. 2004. Taking stock. Identifying Khoekhoen herder rock art in southern Africa. Current Anthropology. 45:Aug.-Oct. (4).

South Africa. Parliament. Department of National Education. 1971. Declaration of a national monument no. 1415. Pretoria : Government Printer.

South Africa. Parliament. Office of the President. 1999. National Heritage Resources Act, no. 25, 1999. Pretoria : Government Printer.

Vaal Teknorama Archives Depot, Vereeniging.

Leslie file 03/13558 : 'The diary of T.N. Leslie', 1939.

122/2. Correspondence 22 May 1970; 2 Aug. 1984.

Sedibeng District Council documents file. 16 Feb. 2001.

Van Riet Lowe, C. 1952. The distribution of prehistoric rock engravings and paintings in South Africa. Archaeological Survey Series 7. Pretoria : Government Printer.

Viljoen, J. 2006. Correspondence. hennoxms@telkomsa.net 8 April.

Viljoen, J. 2006. Personal interview. 2 September, Vereeniging.

Whitley, D.S. \& Annegarn, H.J. 1994. Cation-ratio dating of rock engravings from Klipfontein, Northern Cape. In: Dowson, T.A. \& Lewis-Williams, D. (eds.) Contested images: diversity in southern African rock research : 189-197. Johannesburg : Witwatersrand University Press.

Willcox, A.R. \& Pager, H.L. 1967. The petroglyphs of Redan, Transvaal. South African Journal of Science. Nov., 492-498.

Willemse, M. 1999. Die vestiging en uitbouing van munisipale bestuur en voorstedelike ontwikkeling in Vereeniging tot 1992. Unpublished MA thesis : Potchefstroom University for Christian Higher Education.

Wilson, M. \& Thomson, L. (eds.) 1969. The Oxford history of South Africa. Volume 1. South Africa to 1870. London : Fisher Unwin. 